
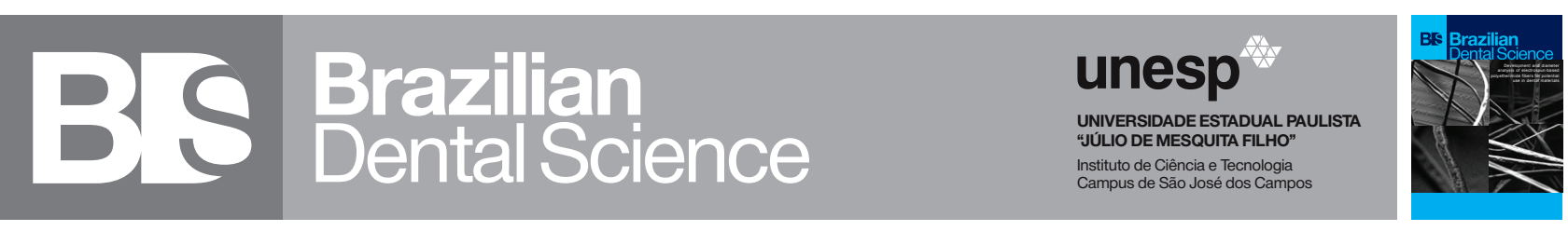

\title{
Estimation of salivary ferritin in children with childhood caries - a cross sectional study
}

\author{
Estimativa da ferritina salivar em crianças com cárie na infância - um estudo transversal
}

Niharika KOTIAN ${ }^{1}$, Deepa GURUNATHAN ${ }^{1}$

1 - Department of Pedodontics, Saveetha Dental College And Hospitals, Saveetha Institute of Medical and Technical Sciences, Saveetha University, Chennai, India.

\section{ABSTRACT}

Objective: Early childhood caries is the presence of dental caries in a child upto seventy one months of age. Saliva plays a major role in maintaining good oral health. The composition of saliva acts as a marker for oral health and the salivary proteins help in modulating the oral microflora in the oral cavity. Some salivary biomarkers help in detecting caries risk and can also predict their prognosis. Ferritin is one of the major biomarkers present in the saliva which acts as an iron binding protein and also as a monitoring tool in children suffering from iron deficiency. The ferritin levels are in increased in serum as well as in saliva to balance the deficiency of iron in the body. Material and methods: Sixty children were selected for the study aged between three to six years. The saliva sample was collected using standard spit method in a sterile container and Ferritin was tested in the samples by Chemiluminescence microparticle immunoassay(CMIA). Results: Salivary ferritin was found to be higher in the saliva of children with early childhood caries(mean value $=5.867$ ) than in children without early childhood caries(mean value $=3.412$ ). Conclusion: A direct association is present between salivary ferritin levels and dental caries. Increased level of ferritin is observed in children with Early childhood caries. Clinical relevance: The level of salivary ferritin is found to be raised in the present study in children with Early childhood caries. The exact mechanism is although not known it can be assumed that the children with early childhood caries might have deficiency of iron which has led to the increased amount of salivary ferritin in the saliva.

\section{KEYWORDS}

Salivary ferritin; Early childhood caries; Salivary proteins; Saliva; Iron deficiency

\section{RESUMO}

Objetivo: A cárie precoce é definida como a presença de cárie dentária em uma criança de até setenta e um meses de idade. A saliva desempenha um papel importante na manutenção de uma boa saúde bucal. A composição da saliva atua como um marcador para a saúde bucal e as proteínas salivares auxiliam na modulação da microflora oral na cavidade oral. Alguns biomarcadores salivares ajudam a detectar o risco de cárie e também podem prever seu prognóstico. A ferritina é um dos principais biomarcadores presentes na saliva, que atua como uma proteína ligadora de ferro e também como uma ferramenta de monitoramento em crianças com deficiência de ferro. Os níveis de ferritina aumentam tanto no soro quanto na saliva para equilibrar a deficiência de ferro no corpo. Material e Métodos: foram selecionadas para o estudo 60 crianças com idades entre três e seis anos. A amostra de saliva foi coletada pelo método padrão de cuspir em um recipiente estéril e a ferritina foi testada nas amostras através de um imunoensaio de micropartículas por quimioluminescência (CMIA). Resultados: A ferritina salivar foi maior na saliva de crianças com cárie na primeira infância (valor médio $=5,867$ ) do que em crianças sem cárie na primeira infância (valor médio $=3,412$ ). Conclusão: Existe uma associação direta entre os níveis de ferritina salivar e a cárie dentária. Nível elevado de ferritina é observado em crianças com cárie na primeira infância. Relevância clínica: $\mathrm{O}$ nível de ferritina salivar está elevado no presente estudo em crianças com cárie na primeira infância. Embora o mecanismo exato seja desconhecido, pode-se presumir que crianças com cárie na primeira infância podem ter deficiência de ferro, o que levou a um aumento na quantidade de ferritina salivar na saliva.

\section{PALAVRAS-CHAVE}

Ferritina salivar; Cárie na primeira infância; Proteínas salivares; Saliva; Deficiência de Ferro. 


\section{INTRODUCTION}

$\mathrm{P}$ resence of one or more decayed (cavitated or non cavitated lesions), missing (due to caries), or filled tooth surfaces in any primary tooth in a child 71 months of age or younger is termed as Early childhood caries [1]. Primary teeth having smooth surface caries when a child is up to 3 years is referred to as severe early childhood caries [2]. Factors responsible in causing Early childhood caries are incorrect feeding practices, constant exposure to carbohydrates and presence of cariogenic microoraganisms in the oral cavity [3]. Streptococcus, Lactobacilli, Actinomyces and Candida has been found to be associated with Early childhood caries [4]. Saliva plays a major role in dental caries as it leads to lubrication of the oral cavity, has an antibacterial action, flushes the oral cavity to remove the food debris in the and also has a buffering action which involves the activity of bicarbonate ions [5]. If the salivary flow is decreased it leads to marked increase in dental caries [6]. Saliva has an essential biomarker called salivary ferritin which plays an important role in storage of iron. Iron is an essential element needed by our body to maintain our health and primary care. Excessive iron is harmful which might lead to life threatening conditions like liver diseases, heart problems as well as diabetes and so is its deficiency which leads to extreme fatigue, chest pain, shortness of breath and pale skin [7]. Iron disorders have several oral manifestations like atrophic glossitis,burning sensation of oral mucosa and generalised oral mucosal atrophy. To overcome disorders related to iron, ferritin is present which is also known as the "housekeeper" storage protein [8]. It was noted that in cases of iron deficiency the level of salivary ferritin in the saliva is increased [910]. The salivary glands are usually impaired in case of any nutritional deficiency which leads to the reduced flow of saliva [11]. This might be a major causative factor of Early childhood caries.
Thus this study is aimed at estimating the level of salivary ferritin in children with and without early childhood caries.

\section{MATERIAL AND METHODS}

The present study was conducted in accordance with the guidelines given by the CONSORT checklist. The study design was reviewed and approved by the institutional review board with ethical number SRB/MDS/ PEDO/18-19/0004. The study includes children between age of three and six years attending outpatient Department of Pediatric Dentistry of a dental institute in Chennai. The research recruited a sample of sixty children. Every child entering the outpatient department and who were willing to participate between the age of three to six years with early childhood caries or without early childhood caries in a span of one week were recruited in the study. Children aged between three to six years were selected as children are more prone to early childhood caries and also tend to have nutritional deficiency in this age group. Ninety children were considered for the study out of which sixty parents had given consent for the participation in the study.

Thirty children had Early childhood caries and the other thirty did not have early childhood caries. All the subjects as well as their parents who were enrolled in the study were informed about the study procedures and a written consent was signed by all the participants.

Children with early childhood caries were selected who were seventy one months of age or younger and whose dmft index was greater than 4 at the age of three years, 5 at the age of four years and 6 at the age of five years [12]. When a carious lesion(s) or both carious lesion(s) and a restoration was present, the tooth was recorded as a d. When a tooth was extracted due to caries, it was recorded as an $\mathbf{m}$. When a permanent or temporary filling was present, or when a filling is defective but not decayed, it was counted as an 
f. Teeth restored for reasons other than caries are not counted as an $\mathrm{f}$. The saliva was collected using standard spit method in a sterile plastic container where the child was asked to accumulate saliva in the floor of the mouth and spit it out in the graduated container [13]. Ferritin was tested in saliva samples using Chemiluminescence microparticle immunoassay (CMIA) in a research laboratory with the help of Ferritin ELISA kit purchased from CUSABIO Inc. Ferritin levels in saliva were represented as $\mathrm{ng} / \mathrm{Ml}$.

\section{Statistical analysis}

The statistical analysis was performed using SPSS software version 17.0. Independent t-test was used to compare the mean values of ferritin level of Non ECC group and ECC group. The significance level was set at $5 \%$ for the present study.

\section{RESULTS}

A total of sixty children participated in the study out of which thirty children had ECC and thirty children did not have early childhood caries. Twenty eight participants were female children and thirty two were male children.

The investigation indicated that salivary ferritin was found to be higher in children with Early childhood caries than in children without Early childhood caries.

The demographic data division for each group of the study is given in table I. Out of sixty children included in the study twenty eight were girls and thirty two were boys between the age group of three to six affected with early childhood caries. Children included in this study had mostly grossly decayed teeth either indicated for pulpectomy or extraction. Children in Non ECC group had no sign of decay in their oral cavity.
Table I - Summary of demographic variables describing sample size and number of males and female participants in each group

\begin{tabular}{|c|ccc|}
\hline Group & Sample size & Female & Male \\
\hline NonECC & 30 & 12 & 15 \\
\hline ECC & 30 & 16 & 17 \\
\hline
\end{tabular}

The mean salivary ferritin level for children without early childhood caries is $3.412 \mathrm{ng} / \mathrm{ml}$ with a standard deviation of 0.793 . The mean salivary ferritin level for children with early childhood caries is $5.867 \mathrm{ng} / \mathrm{ml}$ with a standard deviation of 1.237. Independent t test was performed to compare the salivary ferritin level between both the groups and a statistical significant difference was found $(p<0.05)$. The salivary ferritin level in children with early childhood caries was found to be higher than children without early childhood caries (Table II).

Table II - Ferritin level(mean +standard deviation) and statistical comparison of salivary ferritin level of Non ECC group and ECC group

\begin{tabular}{|cccccc|} 
Group & N & Mean(ng/ml) & $\begin{array}{c}\text { Std. } \\
\text { deviation }\end{array}$ & $\begin{array}{c}\text { Std error } \\
\text { mean }\end{array}$ & P value \\
\hline Ferritin level- & 30 & 3.4120 & 0.79318 & 0.14481 & 0.000 \\
\hline $\begin{array}{c}\text { Non ECC group } \\
\text { ECC group }\end{array}$ & 30 & 5.8677 & 1.23753 & 0.22594 & 0.000 \\
\hline
\end{tabular}

The correlation of both the groups with the normal range is represented in Figure 1. One way annova analysis was done to compare both the grouos with the normal range of salivary ferritin and a non significant difference was observed ( $p>0.05)$. 


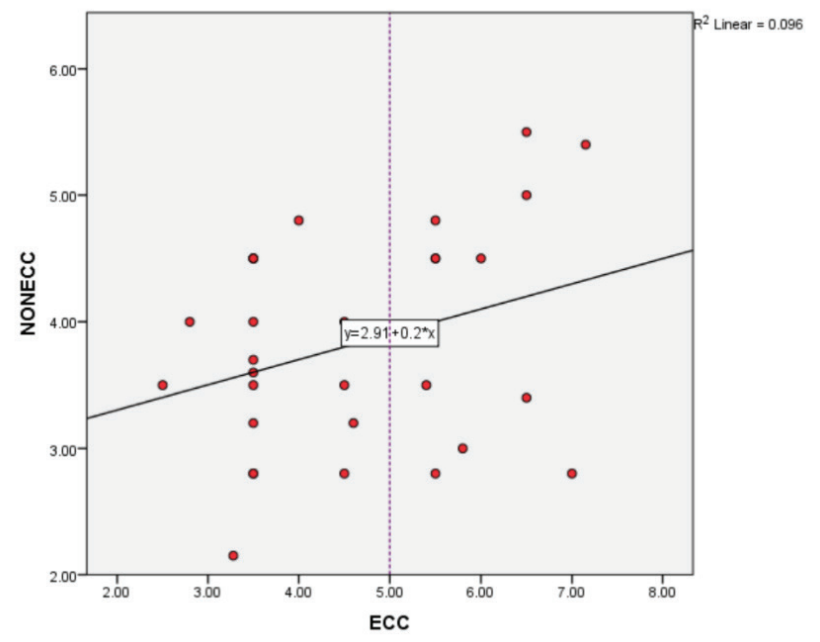

Figure 1 - The scatter plot represents the correlation of ferritin levels of both the groups with the normal range of ferritin in children. $X$ axis represents children with ECC and $Y$ axis represents children without ECC. The purple dotted line represents the normal range of ferritin level $(>5 \mathrm{ng} / \mathrm{ml})$. The red dots represents the ferritin levels in the participants.

\section{DISCUSSION}

In the present study it was noted that children affected with early childhood caries had a higher mean ferritin level than the others children not affected with early childhood caries. Early childhood caries is a major public health problem due to the high prevalence in all areas of the world [12]. Although inappropriate feeding practices, improper maintainance of oral hygiene and microbial infection are some of the etiological factors for Early child hood caries, there are numerous other factors that leads to it. Endogenous factors, such as salivary characteristics along with diet plays an equally pivotal role in the development of early childhood caries [14]. Salivary defense system play a vital role in maintaining a healthy oral cavity [15]. Adequate salivary flow rate is essential to flush debris from thr oral cavity which helps in preventing dental caries. Not much researchers have expressed interest in exploring the correlation between nutritional iron status and caries in children. Thus, the present study was conducted to explore an association of salivary ferritin with early childhood caries.

The prevalence of anemia is high in children worldwide [16] and is about 70\% prevalent in children in India [17]. One of the theories correlating the relationship between iron deficiency and dental caries is that the inflammatory response of the body which is associated with dental caries often lowers haemoglobin level as it leads to the production of cytokines, which further inhibits erythropoiesis [18]. Iron deficiency also impairs the salivary gland leading to reduced salivary flow further causing dental caries [19].

In a review done by Gurunathan et al. [20] it was found that children with severe early childhood caries were more prone to having iron deficiency anemia as well as reduced haemoglobin and ferritin levels.

It can be hypothesised that there is a correlation between dental caries and iron deficiency anemia as due to dental caries the child is unable to eat properly leading to nutritional deficiency further reducing the iron levels and also deficiency of essential vitamins to the body.

In a study done by Jayakumar et al. [21] it was found that serum ferritin was lower in children with early childhood caries. It is essential that a child whose salivary ferritin is higher than the normal range should also be assessed for serum ferritin so as to rule out any nutritional deficiency.

A Child's iron status is known to have an impact on health and primary care. For instance, a child suffering from iron deficiency may not only show neurological manifestations such as learning and memory deficits, decreased fine motor skills, increased anxiety but also weakness, poor physical growth, and compromised immune system, making him/her vulnerable to infections.

Normal level of salivary ferritin in children aged between three and six is greater than $5 \mathrm{ng} /$ $\mathrm{ml}$ as mentioned in the datasheet present in the Ferritin ELISA kit purchased from CUSABIO Inc. Children with Early childhood caries had salivary ferritin present in the range of 3.28 to $7.15 \mathrm{ng} / \mathrm{ml}$ where as children without Early childhood caries had salivary ferritin present in 
the range of 2.15 to $5.4 \mathrm{ng} / \mathrm{ml}$. Few children included in both the groups had ferritin level below the normal range. This may be due to factors like any kind of nutrition deficiency in the body like iron. This factor can be assessed in the near future in relation to this topic.

The level of salivary ferritin is found to be raised in the present study in children with Early childhood caries. The exact mechanism is although not known it can be assumed that the children with early childhood caries might have deficiency of iron which has led to the increased amount of salivary ferritin in the saliva.

The assessment of salivary ferritin is an essential tool in the evaluation of iron stores. The exact mechanism as to why salivary ferritin is raised in children with early childhood caries is not known but it can be speculated that these children and iron deficiency leading to impaired function of salivary gland lowering the salivary flow rate leading to early childhood caries and also it can be speculated that the inflammatory response of the body associated with dental caries might lead to inhibition of erythropoiesis. Children with low iron tend to have increased salivary manganese levels which leads to the retention of salivary ferritin by preventing its transport leading to its increased level in the saliva.

As sufficient literature is not available the exact pathogenesis for the increased level of salivary ferritin cannot be concluded. Since it is clear that salivary ferritin is increased in children with Early childhood caries, salivary ferritin can be used as one of the predictors for development of Early childhood caries or caries in permanent dentition. Future research can be conducted with a larger sample size and more factors can be considered to correlate the association of early childhood caries with salivary ferritin to overcome the limitations of this study. Also repeated saliva samples can be collected from the children for many days to rule out possibilities of nutrition deficiency.

\section{CONCLUSION}

It was concluded based on the discussion and results of this study that there was an association between early childhood caries and salivary ferritin. Increased level of salivary ferritin is seen in children with early childhood caries which can be probably due to the deficiency of iron. It may not be possible to say that a dynamic parameter, which can change with food, such as ferritin can be a predictor of the disease. Therefore, caries lesions may be a confounding variable and not an association with salivary ferritin concentration. Longitudinal studies need to be conducted to assess the levels of salivary ferritin before and after the treatment of Early childhood caries. Further research has to be conducted to correlate levels of serum ferritin and salivary ferritin.

\section{Conflicts of interest}

Deepa Gurunathan declares that she has no conflict of interest. Niharika Kotian declares that she has no conflict of interest.

\section{Funding}

No funding.

\section{Ethical approval}

This article does not contain any studies with human participants or animals performed by any of the authors./All applicable international, national, and/or institutional guidelines for the care and use of animals were followed./ All procedures performed in studies involving human participants were in accordance with the ethical standards of the institutional and/or national research committee and with the 1964 Helsinki declaration and its later amendments or comparable ethical standards.

\section{Informed consent}

Informed consent was obtained from all individual participants included in the study.

Compliance with Ethical standards.

\section{Acknowledgments}

The authors are grateful to Saveetha Institute of Medical and Technical Sciences for granting permission to conduct the present study and the faculties of Department of 
Pediatric Dentistry for their critical review, support during the development and writing of these manuscript.

\section{Conflict of interest}

No potential conflict of interest relevant to this article was reported.

\section{Regulatory Statement}

This study was conducted in accordance with all the provisions of the local human subjects oversight committee guidelines and policies of Saveetha Institute of Medical and Technical Sciences.The approval code for this study is SRB/MDS/PEDO/18-19/0004.

\section{REFERENCES}

1. Hemadi AS, Huang R, Zhou Y, Zou J. Salivary proteins and microbiota as biomarkers for early childhood caries risk assessment. Int J Oral Sci. 2017:9(11):e1.

2. Çolak H, Dülgergil ÇT, Dalli M, Hamidi MM. Early childhood caries update: a review of causes, diagnoses, and treatments. J Nat Sci Biol Med. 2013;4(1):29-38.

3. Feldens CA, Giugliani ERJ, Duncan BB, Drachler M de L, Vítolo MR. Long-term effectiveness of a nutritional program in reducing early childhood caries: a randomized trial. Community Dent Oral Epidemiol. 2010;38(4):324-32.

4. Fan C, Wang W, Xu T, Zheng S. Risk factors of early childhood caries among children in Beijing: a case-control study. BMC Oral Health. 2016;16(1):98.

5. Stookey GK. The effect of saliva on dental caries. J Am Dent Assoc. 2008;139:11S-17S.

6. Jagannathan N, Thiruvengadam C, Ramani P, Premkumar P,Natesan A, Sherlin HJ. Salivary ferritin as a predictive marker of iron deficiency anemia in children. J Clin Pediatr Dent. 2012;37(1):25-30.

7. Giordani A, Haigle J, Leflon P, Risler A, Salmon S, Aubailly M, et al. Contrasting effects of excess ferritin expression on the iron-mediated oxidative stress induced by tert-butyl hydroperoxide or ultraviolet-A in human fibroblasts and keratinocytes. J Photochem Photobiol B. 2000;54(1):43-54.
8. Agarwal PK, Agarwal KN, Agarwal DK Biochemical changes in saliva of malnourished children. Am J Clin Nutr. 1984;39(2):181-4.

9. Canatan D, Akdeniz SK. Iron and ferritin levels in saliva of patients with thalassemia and iron deficiency anemia. Mediterr J Hematol Infect Dis. 2012;4(1):e2012051.

10. Mazengo MC, Tenovuo J, Hausen H. Dental caries in relation to diet, saliva and cariogenic microorganisms in Tanzanians of selected age groups. Community Dent Oral Epidemiol. 1996;24(3):169-74.

11. Iorgulescu G. Saliva between normal and pathological: important factors in determining systemic and oral health. J Med Life . 2009;2(3):303-7.

12. Policy on early childhood caries (ECC): classifications, consequences and preventive strategies. Pediatr Dent. 2008;30:40-3.

13. Bhattarai KR, Kim HR, Chae HJ. Compliance with saliva collection protocol in healthy volunteers: strategies for managing risk and errors. Int J Med Sci. 2018;15(8):823-31.

14. Tsai Al, Chen C-Y,LiL-A, Hsiang C-L, Hsu K-H. Risk indicators for early childhood caries in Taiwan. Community Dent Oral Epidemiol. 2006;34(6):43745.

15. Mahantesha T, Reddy KP, Ellore VPK, Ramagoni NK, litagi V, Ks A. Evaluation and association of iron deficiency anemia with salivary $\mathrm{pH}$ and buffering capacity in children aged 6-12 years. Natl J Physiol Pharm Pharmacol. 2014;4(3):229-32

16. Killip S, Bennett JM, Chambers MD. Iron deficiency anemia. Am Fam Physician. 2007;75(5):671-8.

17. Lueangpiansamut J, Chatrchaiwiwatana S, Muktabhant B, Inthalohit W. Relationship between dental caries status, nutritional status, snack foods, and sugar-sweetened beverages consumption among primary schoolchildren grade 4-6 in Nongbua Khamsaen school, Na Klang district, Nongbua Lampoo Province, Thailand. J Med Assoc Thail Chotmaihet Thangphaet. 2012;95(8):1090-7.

18. Miguel JC, Bowen WH, Pearson SK. Effects of frequency of exposure to iron-sucrose on the incidence of dental caries in desalivated rats. Caries Res. 1997;31(3):238-43.

19. Jagannathan N, Neelakantan P, Ramani P, Premkumar P, Natesan A, Sherlin HJ. Salivary ferritin: a concise update on current concepts. Int J Curr Res Rev. 2012;4(5):58-62.

20. Gurunathan D, Swathi A, Kumar MS. Prevalence of iron deficiency anemia in children with severe early childhood caries. Biomed Pharmacol J. 2019;12(1):219-25

21. Jayakumar A, Gurunathan D. Estimation of ferritin levels in children with and without early childhood caries: a case-control study. J Adv Pharm Edu Res. 2017;7(1):15-7.

\section{Niharika Kotian}

(Corresponding address)

Post-Graduate Student, Department Of Pedodontics, Saveetha Dental College And Hospitals,

Saveetha Institute of Medical and Technical Sciences, Saveetha University,

Chennai, India. Tamil Nadu, India.

Email: niharikagkotian@gmail.com

Date submitted: 2020 Apr 08

Accept submission: 2020 Nov 11 